\title{
Potential increase in photosynthetic response of taro (Colocasia esculenta L.) to photon flux density and elevated $\mathrm{CO}_{2}$
}

\begin{tabular}{|c|c|c|}
\hline Paper received: 17.11.2017 & Revised received: 03.03.2018 & Re-revised received: 10.07.2018 \\
\hline
\end{tabular}

\section{Authors Info \\ V. Ravi ${ }^{1 *}$, S.J. More', R. \\ Saravanan', G. Byju', M. \\ Nedunchezhiyan ${ }^{4}$, A.A. Devi ${ }^{3}$ and \\ K.P. Nair ${ }^{1}$ \\ 'Division of Crop Production, \\ ICAR -Central Tuber Crops \\ Research Institute, \\ Thiruvananthapuram-695 017, India \\ 2Division of Crop Utilization, \\ ICAR - Central Tuber Crops \\ Research Institute, \\ Thiruvananthapuram-695 017, India \\ ${ }^{3}$ Division of Crop Improvement, \\ ICAR-Central Tuber Crops \\ Research Institute, \\ Thiruvananthapuram-695 017, India \\ ${ }^{4}$ ICAR- Regional Centre of Central Tuber Crops Research Institute, \\ Bhubaneswar-751 019, India}

*Corresponding Author Email : veluravi03@yahoo.co.in

\section{Edited by \\ Dr. A.K. Trivedi}

Reviewed by

Dr. Renu Pandey

Dr. Fernando Lidon

\section{Abstract}

Aim: The present study was undertaken to study the net photosynthetic rate $\left(P_{n}\right)$, stomatal conductance $\left(g_{s}\right)$ and intercellular $\mathrm{CO}_{2}\left(\mathrm{C}_{\mathrm{i}}\right)$ in five eddoe and four dasheen type taro genotypes under ambient and elevated $\mathrm{CO}_{2}$, and subjected to different photon flux densities.

Methodology: The critical evaluation of $P_{n}$ was assessed at different photosynthetic photon flux densities (PPFDs) viz., 200, 400, 600, 800, 1000, 1200 and $1500 \mu \mathrm{mol} \mathrm{m}^{-2} \mathrm{hr}^{-1}$ under ambient $\mathrm{CO}_{2}(400$ ppm) and at saturation PPFD $\left(1500 \mu \mathrm{mol} \mathrm{m}^{-2} \mathrm{hr}^{-1}\right)$ at short-term (ten $\mathrm{min}$ ) exposure of leaves to elevated $\mathrm{CO}_{2}\left(\mathrm{eCO}_{2} ; 600,800\right.$ and $\left.1000 \mathrm{ppm}\right)$ at $30^{\circ} \mathrm{C}$ using portable photosynthesis system LI-6400, LICOR, USAin a controlled-climate cuvette system.

Results: The $P_{n}$ in the leaves of nine taro genotypes persistently augmented upon short-term (10 min) exposure to $\mathrm{eCO}_{2}$ concentrations which ranged between $400 \mathrm{ppm}$ and $1000 \mathrm{ppm}$. Taro genotypes exhibited $61.80-113.3 \%$ hike in $\mathrm{P}_{\mathrm{n}}$ at $\mathrm{eCO}_{2}(1000$ $\mathrm{ppm}$ ) as compared to ambient $\mathrm{CO}_{2}(400 \mathrm{ppm})$. However, the per cent increase in $\mathrm{P}_{\mathrm{n}}$ at $\mathrm{eCO}_{2}$ for every 200 ppm between 400 to 1000 ppm significantly declined (4.4-18.4\%) at $1000 \mathrm{ppm} \mathrm{CO}_{2}$. The differences in $g_{s}$ were statistically significant across taro genotypes $(P>0.001)$ and $\mathrm{CO}_{2}$ concentrations $(P>0.001)$. Further, the $C_{i}$ was also found to increase constantly at $\mathrm{eCO}_{2}$ concentrations (400 ppm to $1000 \mathrm{ppm}$ ). However, there was significant reduction (16.2-31.3\%) in C.for every 200 ppm between 400-1000 ppm.

Interpretation: Results of the study revealed that the genotypes Muktakeshi, Sree Pallavi and Telia are promising in the context of climate change as they

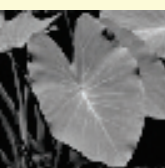
Taro (Colocasia esculenta) genotypes transiently exposed to $\mathrm{CO}_{2}$ concentrations of 400,600 , 800 and 1000 ppm

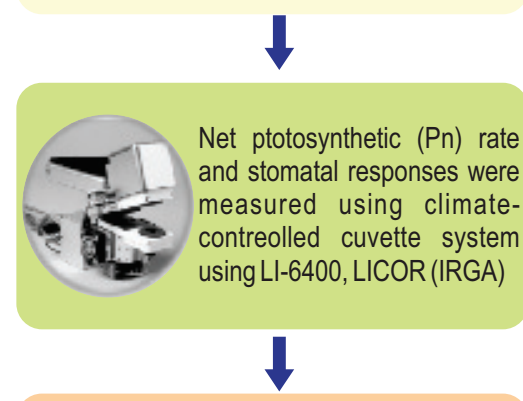

The nine taro genotypes had 61.80 $113.3 \%$ hike in $\mathrm{Pn}$ at $\mathrm{eCO}_{2}$ (1000 ppm) as compared to ambient $\mathrm{CO}_{2}(400) \mathrm{ppm}$

$>$ Short-term exposure are similar to results reported in other crops under long-term exposure to $\mathrm{eCO}_{2}$

$>$ Genotypes such as Muktakeshi, Sree Pallavi and Telia are promising for $\mathrm{eCO}_{2}$ in the context of climate change.

Key words: Colocasia esculenta, Climate change, Elevated $\mathrm{CO}_{2}$, Net photosynthesis, Stomatal conductance

How to cite : Ravi, V., S.J. More, R. Saravanan, G. Byju, M. Nedunchezhiyan, A.A. Devi and K.P. Nair: Potential increase in photosynthetic response of taro (Colocasia esculenta L.) to photon flux density and elevated $\mathrm{CO}_{2}$.J. Environ. Biol., 40, 111-118 (2019). 


\section{Introduction}

Taro [Colocasia esculenta (L.) Schott] belongs to the monocotyledonous family Araceae. Taro, a herbaceous and perennial root crop, is the fourteenth most important vegetable crop worldwide in terms of consumption (Lebot and Aradhya, 1991). Taro plant is grown for an underground starchy corm which produces at its apex a whorl of large leaves with long petioles and bears lateral cormels (Ubalua et al., 2016). Taro corms contain carbohydrates, proteins, essential minerals like potassium, calcium, phosphorous, vitamins and dietary fibres (Kobayashi et al., 2011; Mergedus et al., 2015). All the parts of taro plant are consumed including corms, cormels, leaves, stalks and inflorescence. Taro leaf is reported to be a rich source of carotene, potassium, calcium, phosphorous, iron, riboflavin, thiamine, niacin, vitamin $A$, vitamin $C$ and dietary fibre (Bradburry and Holloway, 1988). Nutritionally, taro corm and cormels contains more than twice the carbohydrate content of potatoes and yield

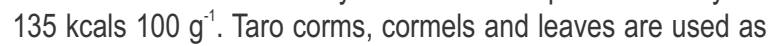
vegetable and consumed after roasting or boiling, or used in various diet preparations. Taro corm flour can be used in bread, cookies, baby food, pasta or other products; and also for diabetics and weaning food for infants and for those with gastrointestinal disorders (Temesgen and Retta, 2015). Taro is also used to cure tuberculosis, ulcers, pancreatic disease, inflammatory bowel and gall bladder disease and fungal infection (Emmanuel-lkpeme et al., 2007; Singh et al., 2012).

Taro cultivation is mostly confined to the tropics, subtropics and in many warmer regions of temperate region where it is treated as a staple or supplementary food. It is largely produced and consumed in many Pacific Island countries, the Caribbean, Asia, Africa (Nigeria, Cameroon, Ghana, Ivory coast, Zaire (Congo) and Burkina Faso) and Ethiopia (Akwee et al., 2015; Chaïr et al., 2016; Banjaw, 2017), while Nigeria being the world's largest taro producer (Ayogu et al., 2015). It can grow under wide range of conditions, varying from wetland to well drained upland conditions under irrigation. The yield per hectare of corms and cormels vary between 5 and 40 tonnes whereas crop duration period vary between 5 and 18 months depending upon the variety and ago-climatic conditions. The production of taro corms and cormels all across the globe is estimated to be around 11.8 million tons annum ${ }^{-1}$ (Vishnu et al., 2012), which is produced from about 2 million ha area with productivity of $6 \mathrm{tha}^{-1}$. Marginal farmers of developing countries are the major contributor of global production of taro which rely upon minimum external resource input system (Singh et al., 2012).

Global warming is a well established fact. The relentless increase in the atmospheric $\mathrm{CO}_{2}$ concentration since 1950 due to anthropogenic activities of human is the major concern of global climate change (More et al., 2017). The atmospheric $\mathrm{CO}_{2}$ was found to be $316 \mathrm{ppm}$ during 1959 which steadily increased to 408 ppm at present, and is expected to increase to $700-900$ ppm by the end of $21^{\text {st }}$ century (IPCC, 2001). During the past five years between 2013 and 2017, the average rate of raise in global $\mathrm{CO}_{2}$

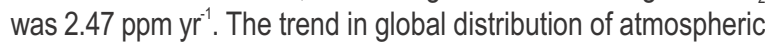
$\mathrm{CO}_{2}$ also indicates a $\mathrm{CO}_{2}$ concentration higher than $400 \mathrm{ppm}$ during 2014 in countries located at higher latitude in the northern hemisphere. India, being the fourth country in the world of annual $\mathrm{CO}_{2}$ emission, also had an increasing trend of $\mathrm{CO}_{2}$ emission into the atmosphere and released $2088 \times 10^{6}$ tonnes $\mathrm{CO}_{2}$ during 2014 (http://euanmearns .com/the-record-of-recent-man-made- $\mathrm{CO}_{2}$ emissions-1965-2014/).

The concentration of $\mathrm{CO}_{2}$ significantly affects plant photosynthesis and stomatal physiology. $\mathrm{C}_{3}$ plants significantly respond to $\mathrm{eCO}_{2}$ which can effectively influence the productivity (Lawlor and Mitchell, 2000). Photosynthetic efficiency was increased by two folds when plants were exposed to 700 as compared to $380 \mathrm{ppm}$ (Ainsworth and Long, 2005). Elevated $\mathrm{CO}_{2}$ in $\mathrm{C}_{3}$ plants consequently intensified net photosynthetic and biomass accumulation by the virtue of significant $\mathrm{CO}_{2}$ uptake (Cruz et al., 2014). Yields of many cereal, legume and vegetable crops have significantly increased at various elevated $\mathrm{CO}_{2}$ concentrations (Singh and Jasrai, 2012; O'Leary et al., 2015; Zhang et al., 2015). In potato, tuber yield was increased at 1000 ppm (Wheeler et al., 1994). Sweet potato also responded positively as storage root yield has been shown to increase up to

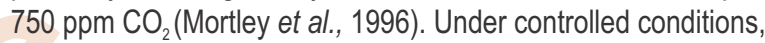
sweet potato photosynthetic rate increased due to increase in $C$ from 250 to $560 \mathrm{ppm}$ and the response was temperature dependent (Cen and Sage, 2005). Czeck et al. (2012) observed a significant increase in both above (31-43\%) and below (61-101\%) ground biomass at $1520 \mathrm{ppm}$ depending upon the organic/ inorganic source of nutrients in sweet potato. The accumulation of below-ground biomass, appreciably greater than the aboveground biomass, highlights the importance of root crops under high $\mathrm{CO}_{2}$ environment. Understanding genotypic responses to $\mathrm{eCO}_{2}$ is, therefore, essential to identify genotypes with efficient $\mathrm{CO}_{2}$ capture potential trait for breeding varieties for changing climate. Although, taro being a $\mathrm{C}_{3}$ plant has the advantage of responding positively to an increase in atmospheric $\mathrm{CO}_{2}$, the photosynthetic response of taro to $\mathrm{CO}_{2}$ concentrations and photon flux density has not yet been studied. In view of the above, the present study aimed to investigate the photosynthetic response of nine field grown taro genotypes to elevated $\mathrm{CO}_{2}$ and photosynthetic photon flux densities.

\section{Materials and Methods}

Plant material and growth conditions: Cormels of five eddoe type taro genotypes viz., Sree Pallavi, Muktakesi, Jhankri, (varieties) and Telia and Topi (farmers' varieties from Odisha) and four dasheen type taro genotypes viz., NM/2017-1 (source: Nayagarh, Odisha), NM/2017-2, (source: Chakkapada, Odisha), NM/2017-3 (source: Jalandhar market) and VHAK/2017-4 (source: Joida, Karnataka) were grown under irrigated conditions 
during April - August 2017 in the farm of ICAR-Central Tuber Crops Research Institute, Thiruvananthapuram. There were three replications and each replication had twenty five plants. $\mathrm{N}$ : $\mathrm{P}_{2} \mathrm{O}_{5}: \mathrm{K}_{2} \mathrm{O}$ were applied @ 100: 25: $100 \mathrm{~kg} \mathrm{ha}^{-1}$ as per the package of practices as advocated by Ravindran et al. (2013). Plants were grown under open sunlight conditions with $\approx 12 \mathrm{hr}$ sun light $\mathrm{d}^{-1}$ under $\approx 1700 \mu \mathrm{mol} \mathrm{m}^{-2} \mathrm{hr}^{-1}$ at $30^{\circ} \mathrm{C} \pm 2^{\circ} \mathrm{C}$ during d time and $23^{\circ} \mathrm{C} \pm$ $1^{\circ} \mathrm{C}$ during night time. Weed control mat was used to control weed growth in the field. The diurnal changes of atmospheric $\mathrm{CO}_{2}$ in the field indicated a dip from $\sim 470 \mathrm{ppm}$ at 6.00 a.m. to $\sim 380 \mathrm{ppm}$ at 12.00 a.m. and raising to $\sim 400 \mathrm{ppm}$ at $4.0 \mathrm{p} . \mathrm{m}$.

Estimation of leaf photosynthetic and biochemical parameters : Photosynthetic and biochemical parameters were measured in fully developed $2^{\text {nd }}$ and $3^{\text {rd }}$ leaf from a healthy taro plant during $4^{\text {th }}$ month after planting. The net photosynthetic rate $\left(P_{n}\right)$, stomatal conductance $\left(g_{s}\right)$ and sub-stomatal/intercellular $\mathrm{CO}_{2}\left(C_{i}\right)$ were recorded under short-term exposure (10 $\mathrm{min}$ ) to $\mathrm{CO}_{2}$ concentrations viz., $400,600,800,1000 \mathrm{ppm}$ at $30^{\circ} \mathrm{C}$ and $1500 \mu \mathrm{mol} \mathrm{m} \mathrm{hr}^{-1}$ photosynthetic photon flux density (PPFD) in a controlled-climate cuvette of a portable photosynthesis measurement system (Li-6400; Li-Cor, Lincoln, NE, USA). The $\mathrm{CO}_{2}$ in the air entering the leaf chamber was calibrated to $400 \mathrm{ppm}$ in ambient and to 600,800 and $1000 \mathrm{ppm}$ in elevated $\mathrm{CO}_{2}$ using $\mathrm{CO}_{2}$ cartridge. The light response curve was recorded by measuring Pn at different PPFDs viz., 200, 400, 600, 800, 1000, 1200 and $1500 \mu \mathrm{mol} \mathrm{m} \mathrm{hr}^{-1} 30^{\circ} \mathrm{C}$ at $400 \mathrm{ppm} \mathrm{CO}_{2}$ level. In the leaves, the total chlorophyll content was estimated by the method of Lichtenthaler (1987), and the total protein content was estimated according to Bradford (1966). The data were statistically analyzed using SAS/Software Version 9.3, SAS Institute Inc., Cary, NC, USA2010.

\section{Results and Discussion}

Increase in PPFD from 200 to $1500 \mu \mathrm{mol} \mathrm{m}^{-2} \mathrm{sec}^{-1}$ steadily increased $P_{n}$ of nine taro genotypes. Although maximum $P_{n}$ rate was recorded at $1500 \mu \mathrm{mol} \mathrm{m} \mathrm{sec}^{-1} \mathrm{PPFD}$, while the increase in $P_{n}$ at PPFD $>600 \mu \mathrm{mol} \mathrm{m} \sec ^{-1}$ was insignificant (Fig. 1). The $P_{n}$ significantly differed across nine taro genotypes and within PPFDs $(P<0.001)$; the interaction effect of genotypes and PPFDs on $P_{n}$ was significant $(P<0.001)$. The $P_{n}$ steadily increased during short term exposure to $\mathrm{eCO}_{2}$ concentration from $400 \mathrm{ppm}$ to 1000 $\mathrm{ppm}$ in the leaves of nine taro genotypes (Fig. 2A). At 400 ppm $\mathrm{CO}_{2}, \mathrm{P}_{\mathrm{n}}$ varied from $22.36 \mu \mathrm{mol} \mathrm{CO}_{2} \mathrm{~m}^{-2} \mathrm{sec}^{-1}$ in the genotype $\mathrm{NM} / 2017-2$ to $28.52 \mu \mathrm{mol} \mathrm{CO} \mathrm{m}^{-2} \mathrm{sec}^{-1}$ in the genotype NM/2017 -3 . The difference in $P_{n}$ were statistically significant across nine taro genotypes $(P>0.001)$ and different concentrations of $\mathrm{CO}_{2}$ $(P>0.001)$. The interaction effect of genotypes and $\mathrm{CO}_{2}$ concentrations on $P_{n}$ was significant $(P>0.001)$. This evinces the existence of significant genotypic variation for photosynthetic potential across taro genotypes as well as $\mathrm{CO}_{2}$ concentrations. Differential photosynthetic responses, both positive and negative, of higher plants to $\mathrm{eCO}_{2}$ has been reported (Reddy et al., 2010).

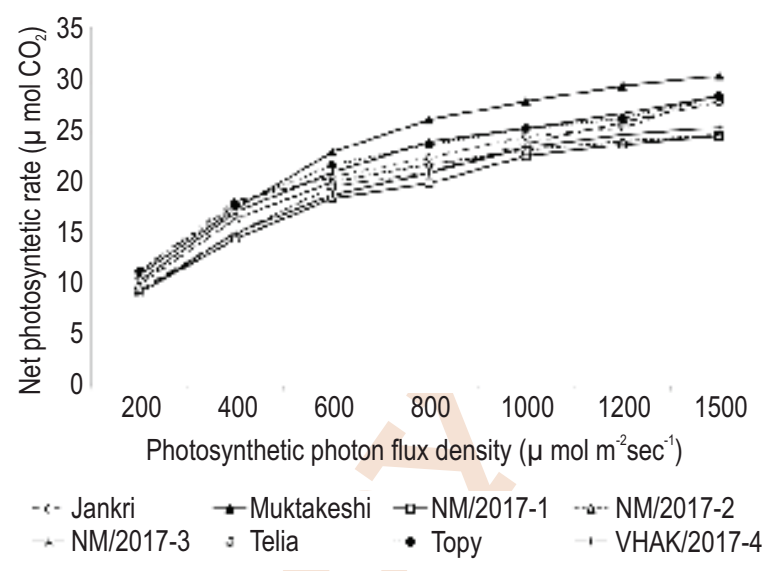

Fig. 1 : Changes in net photosynthetic rate of taro genotypes under differentPPFD.

Such variations have been attributed to differences in experimental conditions, plant species used and plant age, duration of exposure to $\mathrm{eCO}_{2}$ and source-sink activity. Among twelve sweet potato genotypes, the $P_{n}$ was found to steadily increase due to short-term (ten min) exposure at $\mathrm{eCO}_{2}$ concentrations between 400 ppm and 1000 ppm and had a quadratic relation with the increase in $\mathrm{CO}_{2}$ concentration (Ravi et al., 2017). Long-term exposure to $\mathrm{eCO}_{2}$ may result in photosynthetic acclimation due to greater stomatal resistance, higher carbohydrate accumulation, diluted chlorophyll concentrations, feedback inhibition or physical damage at the chloroplast level eventually reducing the photosynthetic capacity. However, such a down regulation of the photosynthetic capacity depends upon the plant species, developmental stage and environmental conditions (Xu et al., 2015). Several studies have reported wide variation in the enhancement of $\mathrm{P}_{\mathrm{n}}$ by $\mathrm{eCO}_{2}$ among cereal, pulses and oil seed crops. Allen and Prasad (2004) demonstrated that in $\mathrm{C}_{3}$ plants photosynthetic activity was higher by $\sim 48 \%$ at $800 \mathrm{ppm} \mathrm{CO}_{2}$ concentration as compared to $400 \mathrm{ppm}$. In sunflower, $P_{n}$ was higher by $45 \%$ at $700 \mathrm{ppm}$ as compared to 350 ppm CO 2 (Tezara et al., 2002) by $30-60 \%$ at 720 ppm as compared to $370 \mathrm{ppm} \mathrm{CO}_{2}$ in sugarcane (De Souza et al., 2008), and by $\sim 70 \%$ at $550 \mathrm{ppm}$ as compared to $370 \mathrm{ppm} \mathrm{CO}$ in chickpea (Madan Pal and Sangeeta, 2009). On the contrary, in cassava, $P_{n}$ rates did not differ significantly at $750 \mathrm{ppm}$ as compared to $390 \mathrm{ppm}$ under long term and controlled conditions (Cruz et al., 2016) or had insignificant effect on $P_{n}$ at 550 ppm, however $P_{n}$ significantly decreased $P_{n}$ at 710 ppm as compared to 360 ppm (Gleadow et al., 2009). Photosynthetic acclimation and decrease in stomatal conductance $\left(g_{s}\right)$ might be a possible mechanism for the non-significant increase in $\mathrm{P}_{\mathrm{n}}$ (Cruz et al., 2016).

In the present study, the $\mathrm{P}_{\mathrm{n}}$ rate in taro varieties increased steadily at elevated $\mathrm{CO}_{2}$ concentrations (400 - 1000 ppm), 

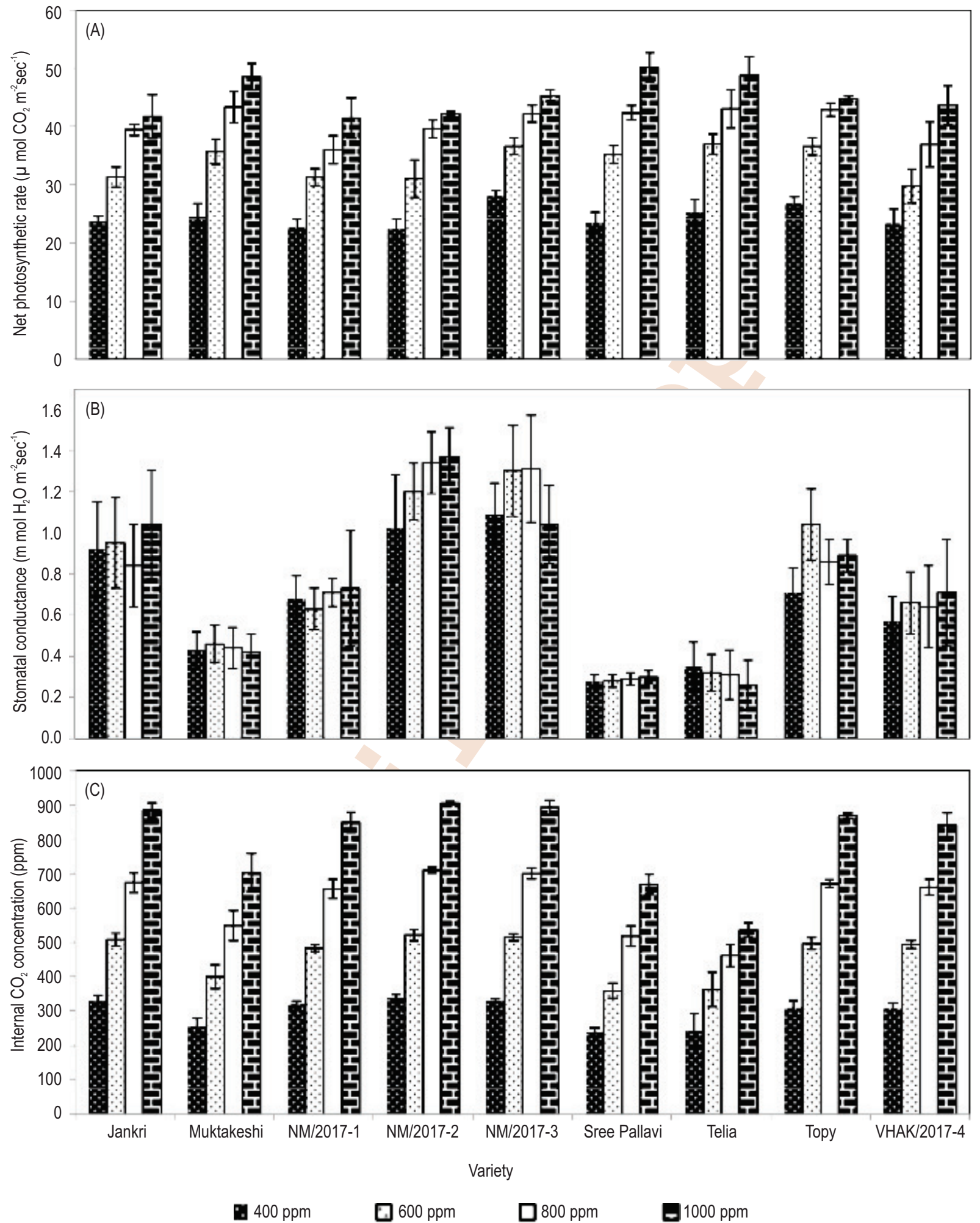

Fig. 2 : Changes in the net photosynthetic rate (A), stomatal conductance (B) and internal $\mathrm{CO}_{2}$ concentration (C) under ambient and eCO concentrations. The error bars indicate standard deviation. 

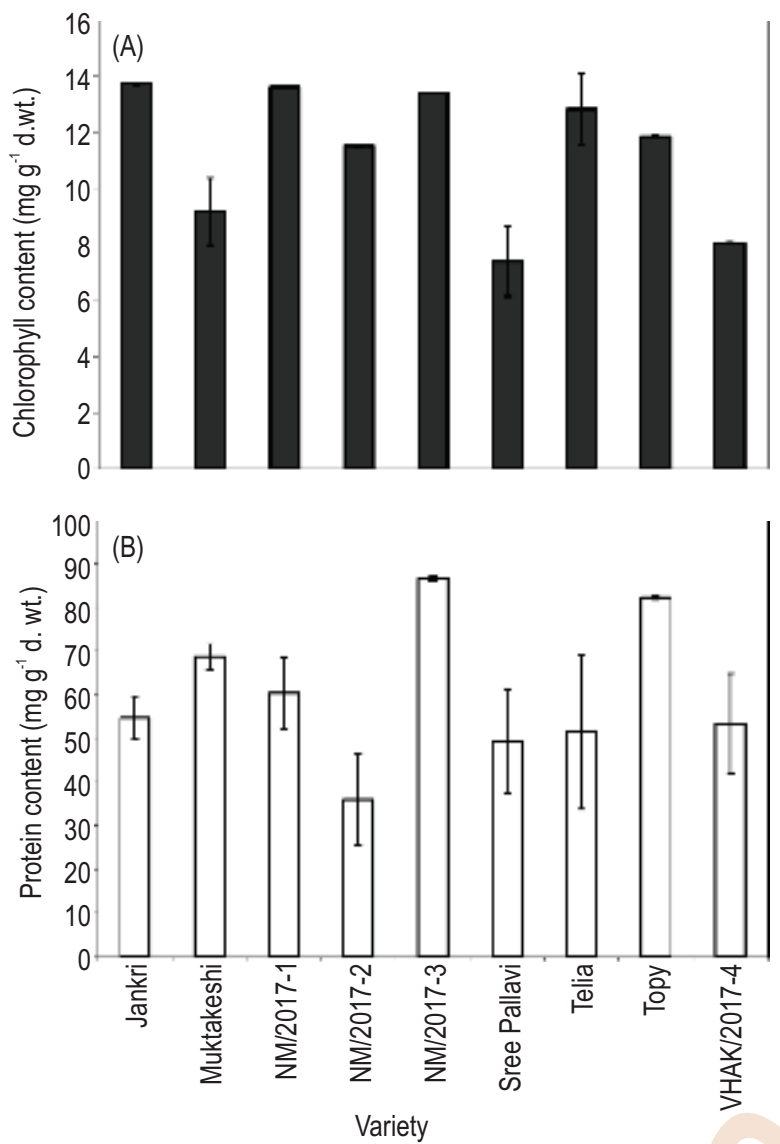

Fig. 3 : Leaf chlorophyll content (A) and protein content (B) of taro genotypes.

however, the increase in $\mathrm{P}_{\mathrm{n}}$ rates diminished steadily with an increase in $\mathrm{CO}_{2}$ concentration between $600 \mathrm{ppm}$ to $1000 \mathrm{ppm}$. While studying the response of cotton to elevated $\mathrm{CO}_{2}$, Reddy et al. (2005) inferred similar results. They reported that the photosynthetic efficiency of cotton plants gradually increased only between $350-700 \mathrm{ppm}$ and was higher at $700 \mathrm{ppm}$. Strikingly, at 900 ppm there was no significant increase in the photosynthetic rate. Similarly, in rice, photosynthetic rates were saturated at 500 ppm after reaching to its maximum value at 500 ppm (Baker et al., 1990). The decrease in increment of $P_{n}$ at short-term exposure to $\mathrm{eCO}_{2}$ is attributed to the factors such as decline in electron transport capacity, ATP: ADP ratio in the chloroplast, capacity of $P_{i}$-regeneration from phosphorylated photosynthetic intermediates, decline in RuBP regeneration and content, decline in the activation state of Rubisco and balance between Rubisco and other processes limiting photosynthesis (Sage et al., 1989; Makino and Mae, 1999; Xu et al., 2016). A decreased photosynthetic rate recorded under $\mathrm{eCO}_{2}$, in the present study, is not attributed to feedback inhibition due to excessive carbohydrate accumulation, the related gene expression and subsequent acclimation. This is because taro plants were not exposed to long term $\mathrm{eCO}_{2}$. Furthermore, there was a decrease (increase in stomatal resistance) or only subtle increase in $\mathrm{g}_{\mathrm{s}}$ as compared to ambient $\mathrm{CO}_{2}$ (discussed in next paragraph). This is in consonance with the previous reports on sweet potato (Ravi et al., 2017) and elephant foot yam (Ravi et al., 2018). The total chlorophyll content in the leaves of nine taro genotypes varied from $7.42 \pm 1.53 \mathrm{mg} \mathrm{g}^{-1}$ dry leaf (Sree Pallavi) to $13.74 \pm 0.04 \mathrm{mg} \mathrm{g}^{-}$ ${ }^{1}$ dry leaf (Jankri; Fig. $3 \mathrm{~A}$ ). In addition, the total protein content

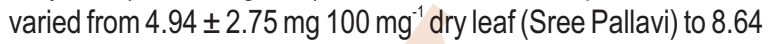
$\pm 0.07 \mathrm{mg} 100 \mathrm{mg}^{-1}$ dry leaf (NM/2017-3; Fig. 3B) The differences in the total chlorophyll and protein content in the leaves of nine taro genotypes were statistically significant. However, $P_{n}$ had no definite correlation with either total chlorophyll or protein content because several researchers have reported that the long-term exposure of leaves to $\mathrm{eCO}_{2}$ had significantly decreased or increased or had no effect on the total chlorophyll or protein content (Bhatt et al., 2010 a, b; Singh and Jasrai, 2012).

The changes in stomatal conductance $\left(g_{s}\right)$ in response to $\mathrm{eCO}_{2}$ varied among nine taro genotypes. The $\mathrm{g}_{\mathrm{s}}$ steadily
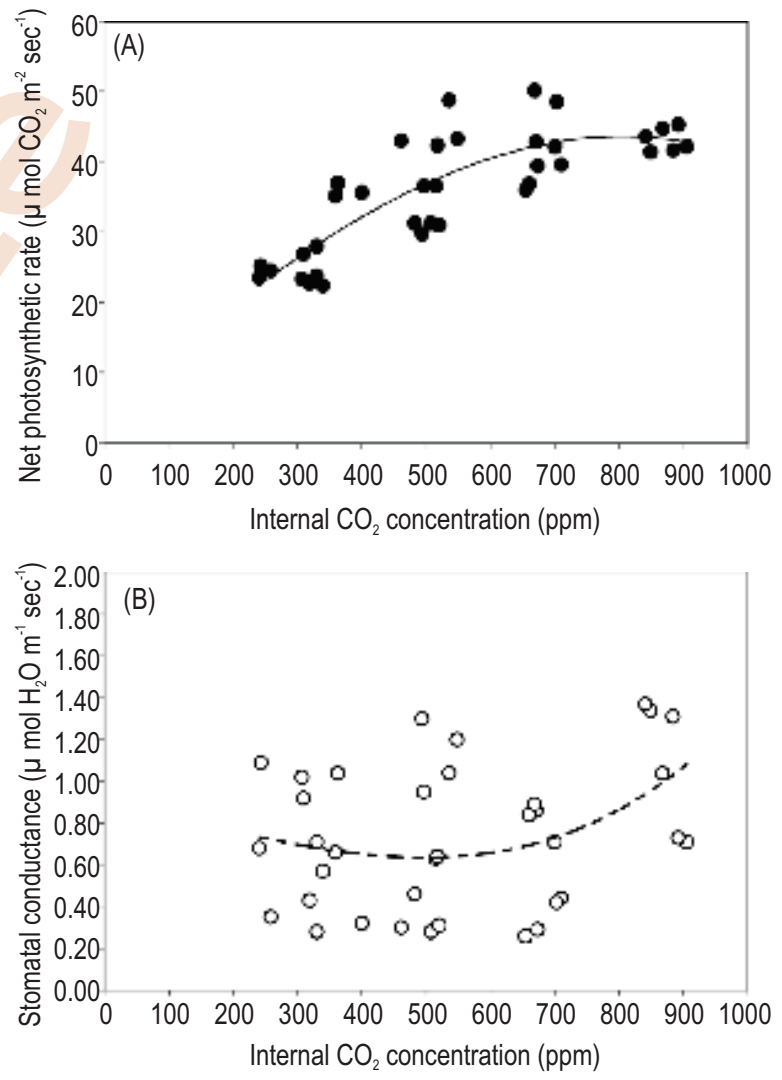

Fig. 4 : Relationship of net photosynthetic rate (A), stomatal conductance (B) with internal $\mathrm{CO}_{2}$ concentration in taro genotypes under $\mathrm{eCO}_{2}$ treatment. 
increased between $400 \mathrm{ppm}$ to $1000 \mathrm{ppm} \mathrm{CO}_{2}$ in the leaves of three taro genotypes viz., NM/2017-2, NM/2017-3 and Sree Pallavi. The differences in $g_{s}$ were statistically significant across taro genotypes $(P>0.001)$ and $\mathrm{CO}_{2}$ concentrations $(P>0.001)$. Genotypes and $\mathrm{CO}_{2}$ concentration interacted significantly on $g_{s}$ $(P>0.05)$. Partial stomatal closure and associated decrease in stomatal conductance to $\mathrm{H}_{2} \mathrm{O}$ is one of the most important response to increasing $\mathrm{CO}_{2}$ (Ainsworth and Rogers, 2007). Among twelve sweet potato genotypes, stomatal conductance steadily decreased at $\mathrm{eCO}_{2}$ concentrations between 400 and 1000 ppm (Ravi et al., 2017). Recently, Xu et al. (2016) reported a reduction in $\mathrm{g}_{\mathrm{s}}$ by $21-50 \%$ at $\mathrm{eCO}_{2}$ in various plant species. The $\mathrm{g}_{\mathrm{s}}$ decreased, on average, by $37 \%$ in eCO $\mathrm{CO}_{2}$ at $720 \mathrm{ppm}$ as compared to $370 \mathrm{ppm}$ in sugarcane (De Souza et al., 2008). Cotton leaves showed $45 \%$ reduced $g_{s}$ activity at $700 \mathrm{ppm} \mathrm{CO}_{2}$ concentration as compared to $350 \mathrm{ppm}$ at $31^{\circ} \mathrm{C}$ (Reddy et al., 2005). In sunflower leaves, the $g_{\mathrm{s}}$ decreased by $\sim 50 \%$ at $700 \mathrm{ppm}$ as compared to 350 ppm CO $\mathrm{CO}_{2}$ (Tezara et al., 2002). Compared to $389 \mathrm{ppm} \mathrm{CO}, \mathrm{eCO}_{2}$ decreased $\mathrm{g}_{\mathrm{s}}$ by $32 \%$ at $550 \mathrm{ppm}$ in mung bean leaf (Hao et al., 2011). Nevertheless, the changes in $g_{s}$ in response to $\mathrm{eCO}_{2}$ appear to vary among genotypes depending on their tolerance to high $\mathrm{CO}_{2}$. Long term exposure to $\mathrm{eCO}_{2}(600 \pm 50 \mathrm{ppm})$ significantly increased $g_{s}$ in two varieties of Avena sativa, Panicum maximum and Stylosanthes hamata, but significantly decreased in one variety of Avena sativa (Bhatt et al., 2010 a, b). According to Ravi et al. (2018) in elephant foot yam stomatal conductance increased at 600 and reaching to maximum at 800 ppm $\mathrm{CO}_{2}$ as compared to $400 \mathrm{ppm} \mathrm{CO}_{2}$. Further it was significantly decreased at $1000 \mathrm{ppm} \mathrm{CO}_{2}$. In the present study, the changes in $\mathrm{g}_{\mathrm{s}}$ in response to $\mathrm{eCO}_{2}$ varied among taro genotypes in consonance with Bhatt et al. (2010 a, b). Taro plants were grown in ambient $\mathrm{CO}_{2}(400 \mathrm{ppm})$, and therefore the decrease in $\mathrm{g}_{\mathrm{s}}$ in leaves during short term measurements at $\mathrm{eCO}_{2}$ (800 and 1000 ppm) as compared to $400 \mathrm{ppm}$ is attributed to partial closure of stomata and not due to decrease in standard deviation and the stomatal index (SI). The increase in $\mathrm{g}_{\mathrm{s}}$ in the taro genotypes viz., Jankri, NM/2017-2, Topi and VHAK/2017-4 evinces greater tolerance to $\mathrm{eCO}_{2}$ environment.

Elevated $\mathrm{CO}_{2}$ concentration (400-1000 ppm) increased the intercellular $\mathrm{CO}_{2}$ concentration $\left(\mathrm{C}_{\mathrm{i}}\right)$ in the leaves of three taro genotypes (Fig. $2 \mathrm{C}$ ). In the present study, although, the $\mathrm{g}_{\mathrm{s}}$ significantly decreased at $\mathrm{eCO}_{2}$ greater than $400 \mathrm{ppm}$ in some genotypes, the decline in the increment of net photosynthetic rate due to increase in $\mathrm{CO}_{2}$ resulted in high intercellular $\mathrm{CO}_{2}$ concentrations which in turn sustained greater net photosynthetic rates at $\mathrm{eCO}_{2}$ as compared to $400 \mathrm{ppm} \mathrm{CO}_{2}$. Results are in consonance with Ravi et al. (2017). In sweet potato, $C_{i}$ augmented constantly due to short-term (10 min) exposure at $\mathrm{eCO}_{2}(400 \mathrm{ppm}$ - 1000 ppm). Strikingly, the per cent increase in $C_{i}$ at $\mathrm{eCO}_{2}$ significantly declined at $\mathrm{CO}_{2}$ concentrations above $600 \mathrm{ppm}$. While working on the effect of elevated $\mathrm{CO}_{2}$ in mung bean leaf, Hao et al. (2011) inferred that $C_{i}$ increased by $9.8 \%$ at 550 ppm as compared to $389 \mathrm{ppm} \mathrm{CO}_{2}$. Increased $\mathrm{C}_{\mathrm{i}}$ rate is responsible for increased $\mathrm{P}_{\mathrm{n}}$ rates in cotton plants under $\mathrm{eCO}_{2}$ (Mauney et al., 1992). Although $\mathrm{eCO}_{2}$ significantly decreased the $g_{s}$ in some genotypes, the $\mathrm{eCO}_{2}$ was adequate to sustain $C_{i}$ at high levels which resulted in decreased photorespiration $\left(P_{r}\right)$ and increased $P_{n}$. The difference in $\mathrm{C}_{i}$ were statistically significant across genotypes and $\mathrm{CO}_{2}$ concentrations $(P>0.001)$. The interaction effect of genotypes and $\mathrm{CO}_{2}$ concentrations on $C_{i}$ was significant $(P>0.001)$. The net photosynthetic rate and stomatal conductance had a quadratic relation $\left(R^{2}=0.692\right)$ (Fig. $\left.4 \mathrm{~A}\right)$ in agreement with Hikosaka et al. (2005) whereas stomatal conductance had an exponential relation $\left(R^{2}=0.143\right)$ with $C_{i}($ Fig. $4 B)$.

The taro genotypes Muktakeshi, Sree Pallavi and Telia are promising for $\mathrm{eCO}_{2}$ in the context of climate change and the mechanism needs to be elucidated. The data on photosynthetic response of taro genotypes to $\mathrm{eCO}_{2}$ can be used for developing modeling of growth and productivity of taro under $\mathrm{eCO}_{2}$ environment. The difference in the response of taro genotypes under short-term exposure to $\mathrm{eCO}_{2}$ warrants further investigation with respect to growth and corm yield under long-term exposure to $\mathrm{eCO}_{2}$.

\section{Acknowledgment}

The authors thank the Director, ICAR-Central Tuber Crops Research Institute, Sreekariyam, Thiruvananthapuram for facilities provided.

\section{References}

Ainsworth, E.A. and S.P. Long: What have we learned from 15 years of free-air $\mathrm{CO}_{2}$ enrichment (FACE)? A meta-analytic review of the responses of photosynthesis, canopy properties and plant production to rising $\mathrm{CO}_{2}$. New Phytol., 165, 351-372 (2005).

Ainsworth, E.A. and A. Rogers: The response of photosynthesis and stomatal conductance to rising $\mathrm{CO}_{2}$ : Mechanisms and environmental interactions. Plant Cell Environ., 30, 258-270 (2007).

Akwee, P.E, G. Netondo, J.A. Kataka and V.A. Palapala: A critical review of the role of taro Colocasia esculenta L. (Schott) to food security: A comparative analysis of Kenya and Pacific Island taro germplasm. Sci. Agric., 9, 101-108 (2015).

Allen, Jr., L.H. and P.V.V. Prasad: Crop responses to e-carbon dioxide. In: Encyclopedia of Plant and Crop Science (Ed.: R.M. Goodman). CRC Press (2004).

Ayogu, C.J., C.U. Ike, O.I. Ogbonna and G.K. Nnaemeka: Agricultural extension roles towards adapting to the effects of Taro leaf blight (Tlb) disease in Nsukka Agricultural Zone, Enugu State. J. Boil. Agric. Hith., 5, 59-72 (2015).

Banjaw, D.T.: Review of Taro (Colocasia esculenta L.)-Genetics and Breeding. J. Hortic., 4, 1 (2017). doi: 10.4172/2376-0354. 1000196.

Baker, J.T., L.H. Allen Jr. and K.J. Boote: Growth and yield response of rice to carbon dioxide concentration. J. Agril. Sci., 115, 313-320 (1990).

Bhatt, R.K., M.J. Baig and H.S. Tiwari: $\mathrm{eCO}_{2}$ influences photosynthetic characteristics of Avena sativa L cultivars. J. Environ. Biol., 31, 813-818(2010a). 
Bhatt, R.K., M.J. Baig, H.S. Tiwari and S. Roy: Growth, yield and photosynthesis of Panicum maximum and Stylosanthes hamata under elevated $\mathrm{CO}_{2}$. J. Environ. Biol., 31, 549-552 (2010 b).

Bradford, M.M.: A rapid and sensitive method for the quantification of microgram quantities of protein utilizing the principle of protein dye binding. Anal. Biochem., 72, 248-254 (1966).

Bradburry, J.H. and W.D. Holloway: Chemistry of tropical root crops: Significance for nutrition and agriculture in the Pacific. ACIAR, Canberra, ACIAR Monograph No. 6, 201 (1988).

Cen, Y.P. and R.F. Sage: The regulation of Rubisco activity in response to variation in temperature and atmospheric $\mathrm{CO}_{2}$ partial pressure in sweet potato. Plant Physiol., 139, 979-990 (2005).

Chaïr, H., R.E. Traore, M.F. Duval, R. Rivallan, A.L.M. Mukherjee, W.J. Aboagye, V. Van Rensburg, M.A.A. Andrianavalona, Pinheiro de Carvalho, F. Saborio, M. Sri Prana, B. Komolong, F. Lawac and V. Lebot: Genetic diversification and dispersal of Taro (Colocasia esculenta (L.) Schott). PLoS ONE, 11, 1-19 (2016).

Cruz, J.L., A.AC. Alves, D.R. LeCain, D.D. Ellis and J.A. Morgan: Effect of elevated $\mathrm{CO}_{2}$ concentration and nitrate: Ammonium ratios on gas exchange and growth of cassava (Manihot esculenta Crantz). Plant Soil, 374, 33-43 (2014).

Cruz, J.L., A.A.C. Alves, D.R. LeCainc, D.D. Ellis and J.A. Morgan: Elevated $\mathrm{CO}_{2}$ concentrations alleviate the inhibitory effect of drought on physiology and growth of cassava plants. Sci. Hort., 210, 122-129 (2016).

Czeck, B.C., A.H. Jahren, J.L. Deenik, S.E. Crow, B.A. Schubert and M. Stewart: Growth, yield and nutritional responses of chambergrown sweet potato to e-carbon dioxide levels expected across the next 200 years. American Geophysical Union, Fall Meeting (2012).

De Souza, A. P., M. Gaspar, E. A. Da Silva, E. C. Ulian, A. J. Waclawovsky, M. Y. Nishiyama Jr., R. V. Dos Santos, M. M. Teixeira, G. M. Souza and M. S. Buckeridge: Elevated $\mathrm{CO}_{2}$ increases photosynthesis, biomass and productivity, and modifies gene expression in sugarcane. Plant Cell Environ., 31, 1116-1127 (2008).

Emmanuel-lkpeme, C.A., C.A. Eneji and U. Essiet: Storage stability and sensory evaluation of taro chips fried in palm oil, palm olein oil, groundnut oil, soybean oil and their blends. Pakistan J. Nutr., 6 , 570-575 (2007).

Gleadow, R.M., J.R. Evans, S. McCaffery and T.R. Cavagnaro: Growth and nutritive value of cassava (Manihot esculenta Cranz.) are reduced when grown in elevated $\mathrm{CO}_{2}$. Plant Biol., 11, 76-82 (2009).

Hikosaka, K., Y. Onoda, T. Kinugasa, H. Nagashima, N.P.R. Anten and T. Hirose: Plant responses to $\mathrm{eCO}_{2}$ concentration at different scales: Leaf, whole plant, canopy and population. Ecol. Res., 20, 243-253 (2005).

Hao, X.Y., X. Han, P. Li, H.B. Yang and E.D. Lin: Effects of elevated atmospheric $\mathrm{CO}_{2}$ concentration on mung bean leaf photosynthesis and chlorophyll fluorescence parameters. Ying Yong Sheng Tai Xue Bao, 22, 2776-2780 (2011).

IPCC: Climate Change 2001: The Scientific Basis. Contribution of Working Group I to the Third Assessment Report of the Intergovernmental Panel on Climate Change. Cambridge University Press, Cambridge, United Kingdom and New York, NY, USA, pp. 881 (2001).

Kobayashi, N.I., K. Tanoi, A. Hirose, T. Saito, A. Noda, N. Iwata, A. Nakano, S. Nakamura and T.M. Nakanishi: Analysis of the mineral composition of taro for determination of geographic origin. J. Agric. Food Chem., 59, 4412-4417 (2011).
Lawlor, D.W. and R.A.C. Mitchell: Crop ecosystem responses to climatic change: Wheat. In: Climate change and global crop productivity (Eds.: K.R. Reddy and H.F. Hodges). CABI Publishing, UK, USA (2000).

Lebot, V. and K.M. Aradhya: Isozyme variation in taro (Colocasia esculenta (L.) Schott) from Asia and Oceania. Euphytica, 56, 5566 (1991).

Lichtenthaler, H.K.: Chlorophylls and carotenoids: Pigments of photosynthetic biomembranes. Methods Enzymol., 148, 350-382 (1987).

Madan, P. and K. Sangeeta: Impact of elevated $\mathrm{CO}_{2}$ concentration on growth and yield of chickpea. In: Global climate change and Indian Agriculture: Case studies from the ICAR Network Project (Ed.: P.K. Aggarwal). ICAR, New Delhi (2009).

Makino, A. and T. Mae: Photosynthesis and plant growth at e-levels of $\mathrm{CO}_{2}$. Plant Cell Physiol., 40, 999-1006 (1999).

Mauney, J.R., K.F. Lewin, G.R. Hendrey and B.A. Kimball: Growth and yield of cotton exposed to free air $\mathrm{CO}_{2}$ enrichment (FACE). $\mathrm{CRC}$ Crit. Rev. Plant Sci., 11, 213-222 (1992).

Mergedus, A., J. Kristl, A. Ivancic, A. Sober, V. Sustar, T. Krizan and V. Lebot: Variation of mineral composition in different parts of taro (Colocasia esculenta) corms. Food Chem., 170, 37 -46 (2015).

More Sanket J., V. Ravi and S. Raju. Management of heat stress to enhance growth, photosynthesis and corm yield of elephant foot yam [Amorphophallus paeoniifolius (Dennst.)]. Sci. Agri., 19, 4754 (2017). DOI:10.15192/PSCP.SA.2017.19.2.4754.

Mortley, D., J. Hill, P. Loretan, C. Bonsi, W. Hill, D. Hileman and A. Terse: E-carbon dioxide influences yield and photosynthetic responses of hydroponically-grown sweet potato. Acta Hortic., 440, 31-36 (1996).

O'Leary, G.J., B. Christy, J. Nuttall, N. Huth, D. Cammarano, C. Stockle, B. Basso, I. Shcherbak, G. Fitzgerald, Q. Luo, I. Farre-Codina, J. Palta and $\mathrm{S}$. Asseng: Response of wheat growth, grain yield and water use to $\mathrm{eCO}_{2}$ under a Free-Air $\mathrm{CO}_{2}$ Enrichment (FACE) experiment and modeling in a semi-arid environment. Global Change Biol., 21, 2670-2686 (2015).

Ravi, V., R. Saravanan, G. Byju, K.P. Nair and J. George: Photosynthetic response of sweet potato (Ipomoea batatas) to photon flux density and elevated $\mathrm{CO}_{2}$. Indian J. Agr. Sci., 87, $132-138$ (2017).

Ravi, V., S.J. More, R. Saravanan, K.P. Nair and G. Byju: Evaluation of photosynthetic efficiency of elephant foot yam (Amorphophallus paeoniifolius) to photon flux density and elevated $\mathrm{CO}_{2}$. Current Hort., 6, 55-63 (2018).

Ravindran, C.S., S. Ramanathan and M. Eswaran: Agro techniques of tuber crops, ICAR - Central Tuber Crops Research Institute, pp. 132 (2013).

Reddy, A.R., G.K. Rasineni and A.S. Raghavendra: The impact of global elevated $\mathrm{CO}_{2}$ concentration on photosynthesis and plant productivity. Curr. Sci., 99, 46-57 (2010).

Reddy, K.R., P.V.V. Prasad and V. Gopal Kakani: Crop responses to ecarbon dioxide and interactions with temperature. J. Crop Improv., 13, 157-191 (2005).

Sage, R.F., T.D. Sharkey and J.R. Seemann: Acclimation of photosynthesis to $\mathrm{eCO}_{2}$ in five $\mathrm{C}_{3}$ species. Plant Physiol., 89, 590596 (1989).

Singh, A. and Y.T. Jasrai: Response of crops to e-atmospheric carbondioxide. Proc. Indian Nat. Sci. Acad., 78, 45-49 (2012).

Singh, S., D.R. Singh, F. Faseela, N. Kumar, V. Damodaran and R.C. Srivastava: Diversity of 21 taro (Colocasia esculenta (L.) Schott.) 
accessions of Andaman islands. Genet. Resour. Crop Evol., 59, 821-829 (2012).

Tezara, W., V. Mitchell, S.P. Driscoll and D.W. Lawlor: Effects of water deficit and its interaction with $\mathrm{CO}_{2}$ on the biochemistry and physiology of photosynthesis in sunflower. J. Exp. Bot., 53, 17811791 (2002).

Temesgen, M. and N. Retta: Nutritional potential, health and food security benefits of taro Colocasia esculenta (L.): A review. Food Sci. Quality Manage., 36, 23-30 (2015).

Ubalua, A.O., F. Ewa and O.D. Okeagu: Potentials and challenges of sustainable (Colocasia esculenta) production in Nigeria. J. App. Biol. Biotech., 4, 53-59 (2016).

Vishnu, S.N., S. Muthukrishnan, M.H. Vinaiyaka, L.J. Muthulekshmi,
S.M. Raj, S.V. Syamala and R. Mithun: Genetic diversity of Phytophthora colocasia isolates in India based on AFLP analysis. 3 Biotech, 3, 297-305 (2012).

Wheeler, R.M., C.L. Mackowiak, J.C. Sager and W.M. Knott: Growth of soybean and potato at high $\mathrm{CO}_{2}$ partial pressure. Adv. Space Res. 14, 251-255 (1994).

$\mathrm{Xu}, \mathrm{Z}$., Y. Jiang, B. Jia and G. Zhou: Elevated- $\mathrm{CO}_{2}$ response of stomata and its dependence on environmental factors. Front. Plant Sci., 7, 657 (2016)

Zhang, G., H. Sakai, Y. Usui, T. Tokida, H. Nakamura, C. Zhu, M. Fukuoka, K. Kobayashi and T. Hasegawa: Grain growth of different rice cultivars under $\mathrm{eCO}_{2}$ concentrations affects yield and quality. Field Crops Res., 179, 72-80 (2015). 